\title{
Asymmetry, Handedness and Auricle Morphometry
}

\author{
Asimetría, Lateralidad y Morfometría de la Oreja
}

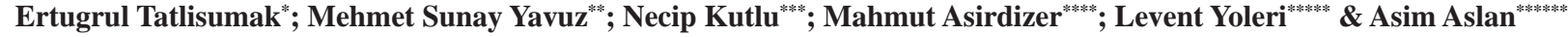

TATLISUMAK, E.; YAVUZ, M. S.; KUTLU, N.; ASIRDIZER, M.; YOLERI, L. \& ASLAN, A. Asymmetry, handedness and auricle morphometry. Int. J. Morphol., 33(4):1542-1548, 2015.

SUMMARY: The aims of this study were to determine various morphometric measurements of auricle, to investigate asymmetry and its relation with handedness in both sexes. Main morphometric measurements of both auricles and hand preferences were determined on 200 male and 200 female healthy university students. All measurements of the auricles were larger in males than the corresponding ones in females and all the differences except earlobe widths were statistically significant. All measurements of left and right auricles were statistically significantly different in both sexes except earlobe length in males, and distance from the highest point of the auricle to the bottom of the intertragic notch and earlobe length in females. Auricle length and distance from the highest point of the auricle to the bottom of the intertragic notch had higher values at the left side and all other measurements were larger at the right side. There was no significant difference between the measurements of the corresponding auricles of the righthanded and lefthanded subjects. All measurements were larger at the right side except auricle length and distance from the highest point of the auricle to the bottom of the intertragic notch in righthanded and lefthanded subjects and all differences except earlobe length were significantly different in righthanded subjects as in the total population but in lefthanded subjects the difference of the auricle width was not significant, either. There was an apparent asymmetry of right and left auricles of normal people in the current study which should be taken in to consideration in plastic surgeries of the external ear, designing the ear devices and forensic applications of earprints.

KEY WORDS: Asymmetry; Handedness; Auricle Morphometry; Lateralization; Anthropometry.

\section{INTRODUCTION}

The auricles are the defining features of the human face. It can be perceived easily that structures of auricle convey signs of age and sex although not easily defined. They are important for the maintainence of a harmonious and pleasing appearance of the face (Brucker et al., 2003; Bozkir et al., 2006). In an anthropometric growth study of external ear in Canadian Caucasians, it was found that the auricle width and auricle length reached the mature size in males at 7 and 13 years and in females at 6 and 12 years; respectively (Farkas et al., 1992). A study from Turkey presented similar results (Kalcioglu et al., 2003).

Knowledge of the morphometry of auricle is important in the diagnosis of congenital malformations and syndromes, in planning the plastic surgeries of the external ear and designing the hearing instruments (Farkas et al.;
Brucker et al.; Kalcioglu et al.; Bozkir et al.). Also it is important in personal identification in forensic sciences (Feenstra \& Van der Lugt 2000; Van der Lugt et al., 2005; Asirdizer et al., 2012).

There were fine and detailed studies on morphometry of the auricle (Farkas et al.; Ferrario et al., 1999; Brucker et al.; Kalcioglu et al.; Barut \& Aktunc, 2006; Bozkir et al.; Purkait \& Singh, 2007) but studies investigating the asymmetry of auricle were very rare (Jung \& Jung, 2003; Liu, 2008) and to our best knowledge there was only one study investigating the relation of auricle asymmetry and hand preference (Jung \& Jung). The aims of this study were to determine various morphometric measurements of right and left auricles, to investigate asymmetry and its relation with handedness in both sexes.

* Celal Bayar University, School of Medicine, Department of Anatomy, Manisa, Turkey.

** Celal Bayar University, School of Medicine, Department of Forensic Medicine, Manisa, Turkey.

*** Celal Bayar University, School of Medicine, Department of Physiology, Manisa, Turkey.

**** Yuzuncu Yil University, School of Medicine, Department of Forensic Medicine, Van, Turkey.

******* Celal Bayar University, School of Medicine, Department of Plastic, Reconstructive and Aesthetic Surgery, Manisa, Turkey.

******** Celal Bayar University, School of Medicine, Department of Otorhinolaryngology and Head and Neck Surgery, Manisa, Turkey. 


\section{MATERIAL AND METHOD}

The study group consisted of 200 male and 200 female healthy undergraduate students of Celal Bayar University with no history of trauma, surgery or congenital anomalies of the auricle. Age of the students ranged between $18-26$ years. All the protocols of this study were approved by The Ethics Committee of Celal Bayar University. All subjects participated in the study voluntarily and were previously informed about all the procedures applied and a written consent was taken from each person.

Age was recorded and weight and height were determined for each participant. Edinburgh Handedness Questionnaire was applied to the subjects to decide about handedness (Oldfield, 1971). Laterality Quotient (LQ) was calculated from the following formula for each participant: $\mathrm{LQ}=100 \times(\mathrm{R}-\mathrm{L} / \mathrm{R}+\mathrm{L})$ and subjects having +30 or higher scores were accepted as righthanded, subjects having scores between +30 and -30 were accepted as ambidexter and subjects having -30 or lower scores were accepted as lefthanded.

Auricle projection (AP) was measured from the helix to the mastoid process at the level of the tragus with a digital caliper (Fig. 1a).

A cardboard containing a graph paper scale was placed to the side of the head surrounding the auricle. Both ears of the subjects were photographed in a standardized manner with a digital photo camera. Making use of the depicted measuring scale in every photograph, following distances were determined in millimeters:

1) Auricle length (AL): The distance between the most superior point of the auricle and the most inferior point of the earlobe on lines paralel to the base of the auricle (Fig. 1b).

2) Distance from the highest point of the auricle to the bottom of the intertragic notch (TIN) (Fig. 1b).

3) Auricle width (AW): The distance between the most anterior and the most posterior points of the auricle (Fig. 1b).

4) Distance from the tragus to helix (TH) (Fig. 1b).

5) Distance from the tragus to antihelix (TAH) (Fig. 1c).

6) Earlobe width (EW): The distance between the most anterior and most posterior points of the earlobe (Fig. 1c).

7) Earlobe length (EL): The distance between the most inferior point of the earlobe, and the deepest point of the intertragic notch (Fig. 1c).

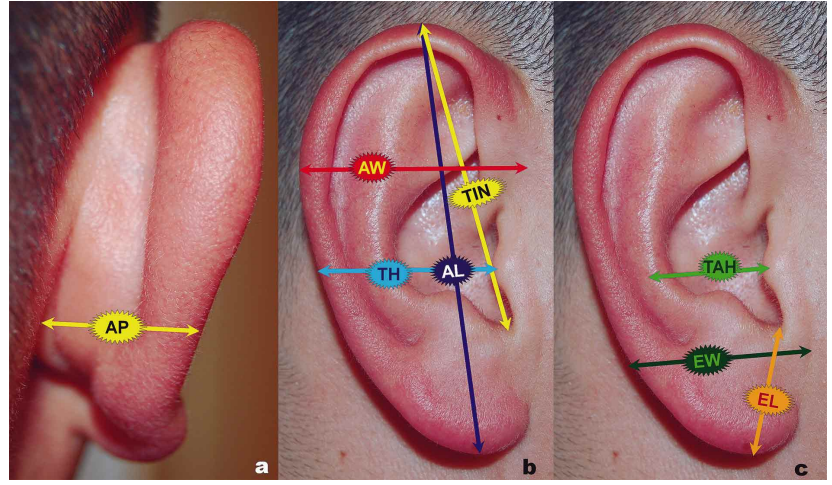

Figure 1. (a) Auricle Projection (AP); (b): Measurements of Ear [Auricle Length (AL); Distance from the Highest Point of the Auricle to the Bottom of the Intertragic Notch (TIN); Auricle Width (AW); Distance from the Tragus to Helix (TH)]; (c): Measurements of Ear [Distance from the Tragus to Antihelix (TAH); Ear Lobe Width (EW); Ear Lobe Length (EL)]

All measurements were taken by two authors (Mehmet Sunay Yavuz and Mahmut Asirdizer) independently and mean values of two measurements were accepted as the measurement. SPSS for Windows 11.5 was used for statistical analysis. Mean + Standard Deviations were used to describe data. The mean age, height and weight were calculated for males and females. Covariance analysis was used to compare difference of means of independent samples adjusting for age. Measurements of the right and left auricles of males were compared with measurements of the auricle of females from the same side. Right and left auricles were compared in males, in females and in the total population. Paired t test was used to compare difference of means of dependent groups. Handedness was expressed in percentage. Measurements of right and left auricles of righthanded and lefthanded subjects were compared respectively by Student's t test. Covariance analysis was used to adjust age distribution of males and females while comparing means. Later, measurements of right and left auricles were compared in righthanded and lefthanded subjects with paired t test.

$\mathrm{P} \leq 0.05$ was accepted as statistically significant and statistically significant differences of measurements were accepted as asymmetry.

\section{RESULTS}

The mean ages of the male and the female subjects were $21.100 \pm 2.1618$ and $20.6300 \pm 2.1415$; respectively.

The height of the males was $176.8250 \pm 6.4297 \mathrm{~cm}$ and the weight was $75.0950 \pm 12.8371 \mathrm{~kg}$. The height was 
$163.0950 \pm 5.5832 \mathrm{~cm}$ and the weight was $59.1450 \pm 8.3740$ in females.

Righthandedness was observed in $91.5 \%$ of subjects in both sexes (183 males and 183 females). $13(6.5 \%)$ of the males and $12(6.0 \%)$ of the females were lefthanded. Ambidexterity was observed in $4(2.0 \%)$ males and in 5 $(2.5 \%)$ females.

Measurements of the right and left auricles of males and females were compared in Table I. All measurements of the auricles were significantly larger in males than females in both sides except EW.
Measurements of the right and left auricles of males, females and total population were compared in Table II. All measurements of the right and left auricles were statistically significantly different in all groups except EL in males and total population, and EL and TIN in females. The values of the AL and TIN were higher at the left side and the other measurements had higher values at the right side in both sexes and total population.

Measurements of the right auricles of righthanded and lefthanded subjects and measurements of the left auricles of righthanded and lefthanded subjects were compared in Table III. The measurements of the right auricles of

Table I. Measurements of the right and left auricles in both sexes.

\begin{tabular}{cccccc}
\hline \multirow{2}{*}{ Mea surement } & $\begin{array}{c}\text { Sex of the } \\
\text { subject }\end{array}$ & \multicolumn{2}{c}{ Right auricle } & \multicolumn{2}{c}{ Left auricle } \\
\cline { 3 - 6 } & Mean \pm SD & P* & Mean \pm SD & P* \\
\hline \multirow{2}{*}{ AL } & Female & $64.4650 \pm 3.4275$ & 0.001 & $65.4900 \pm 3.4510$ & 0.001 \\
& Male & $46.8600 \pm 2.8374$ & 0.001 & $47.3000 \pm 2.8088$ & 0.001 \\
AIN & Female & $44.0500 \pm 2.6443$ & & $44.2900 \pm 2.5708$ & \\
& Male & $35.3250 \pm 3.1383$ & 0.001 & $33.9600 \pm 3.3831$ & 0.001 \\
TH & Female & $32.9650 \pm 2.8184$ & & $32.2850 \pm 2.8626$ & \\
& Male & $27.1250 \pm 2.9467$ & 0.001 & $25.6450 \pm 2.9754$ & 0.001 \\
TAH & Female & $25.5850 \pm 2.4439$ & & $24.1350 \pm 2.8719$ & \\
& Male & $21.3850 \pm 3.2028$ & 0.001 & $19.6950 \pm 3.4014$ & 0.016 \\
EW & Female & $20.2550 \pm 2.7160$ & & $18.6500 \pm 3.1793$ & \\
& Male & $19.2150 \pm 3.3995$ & 0.159 & $17.3300 \pm 3.2378$ & 0.6 \\
EL & Female & $18.7300 \pm 3.4796$ & & $17.0750 \pm 3.1270$ & \\
& Male & $18.4000 \pm 2.1148$ & 0.001 & $18.3700 \pm 2.2379$ & 0.048 \\
& Female & $17.3300 \pm 2.0103$ & & $17.3100 \pm 1.9346$ & \\
& Male & $21.0550 \pm 2.4272$ & 0.001 & $20.5850 \pm 2.4887$ & 0.001 \\
& Female & $19.2000 \pm 2.8231$ & & $18.7000 \pm 2.5203$ & \\
\hline
\end{tabular}

*Adjusted for age by covariance analysis.

Table II. Comparison of the right and left auricles of males, females and total population

\begin{tabular}{|c|c|c|c|c|c|c|c|}
\hline \multirow{2}{*}{ Measureme nt } & \multirow{2}{*}{$\begin{array}{l}\text { Side of the } \\
\text { auricle }\end{array}$} & \multicolumn{2}{|l|}{ Males } & \multicolumn{2}{|c|}{ Females } & \multicolumn{2}{|c|}{ Total population } \\
\hline & & Mean \pm SD & $P^{*}$ & Mean \pm SD & $\mathbf{P}^{*}$ & $\operatorname{Mean} \pm$ SD & $\mathbf{P}^{*}$ \\
\hline \multirow{2}{*}{$\mathbf{A L}$} & Right & $64.4650 \pm 3.4275$ & \multirow{2}{*}{0.001} & $60.2950 \pm 3.1873$ & \multirow{2}{*}{0.001} & $62.3800 \pm 3.9095$ & \multirow{2}{*}{0.001} \\
\hline & Left & $65.4900 \pm 3.4510$ & & $61.3300 \pm 3.1465$ & & $63.4100 \pm 3.9006$ & \\
\hline \multirow{2}{*}{ TIN } & Right & $46.8600 \pm 2.8374$ & \multirow{2}{*}{0.006} & $44.0500 \pm 2.6443$ & \multirow{2}{*}{0.097} & $45.4550 \pm 3.0792$ & \multirow{2}{*}{0.002} \\
\hline & Left & $47.3000 \pm 2.8088$ & & $44.2900 \pm 2.5708$ & & $45.7950 \pm 3.0825$ & \\
\hline \multirow{2}{*}{$\mathbf{A W}$} & Right & $35.3250 \pm 3.1383$ & \multirow{2}{*}{0.001} & $32.9650 \pm 2.8184$ & \multirow{2}{*}{0.001} & $34.1450 \pm 3.2046$ & \multirow{2}{*}{0.001} \\
\hline & Left & $33.9600 \pm 3.3831$ & & $32.2850 \pm 2.8626$ & & $33.1225 \pm 3.2402$ & \\
\hline \multirow{2}{*}{ TH } & Right & $27.1250 \pm 2.9467$ & \multirow{2}{*}{0.001} & $25.5850 \pm 2.4439$ & \multirow{2}{*}{0.001} & $26.3550 \pm 2.8114$ & \multirow{2}{*}{0.001} \\
\hline & Left & $25.6450 \pm 2.9754$ & & $24.1350 \pm 2.8719$ & & $24.8900 \pm 3.0167$ & \\
\hline \multirow{2}{*}{ ТАН } & Right & $21.3850 \pm 3.2028$ & \multirow{2}{*}{0.001} & $20.2550 \pm 2.7160$ & \multirow{2}{*}{0.001} & $20.8200 \pm 3.0192$ & \multirow{2}{*}{0.001} \\
\hline & Left & $19.6950 \pm 3.4014$ & & $18.6500 \pm 3.1793$ & & $19.1725 \pm 3.3295$ & \\
\hline \multirow{2}{*}{$\mathbf{E W}$} & Right & $19.2150 \pm 3.3995$ & \multirow{2}{*}{0.001} & $18.7300 \pm 3.4796$ & \multirow{2}{*}{0.001} & $18.9725 \pm 3.4440$ & \multirow{2}{*}{0.001} \\
\hline & Left & $17.3300 \pm 3.2378$ & & $17.0750 \pm 3.1270$ & & $17.2025 \pm 3.1815$ & \\
\hline \multirow{2}{*}{$\mathbf{E L}$} & Right & $18.4000 \pm 2.1148$ & \multirow{2}{*}{0.780} & $17.3300 \pm 2.0103$ & \multirow{2}{*}{0.844} & $17.8650 \pm 2.1291$ & \multirow{2}{*}{0.735} \\
\hline & Left & $18.3700 \pm 2.2379$ & & $17.3100 \pm 1.9346$ & & $17.8400 \pm 2.1555$ & \\
\hline \multirow{2}{*}{$\mathbf{A P}$} & Right & $21.0550 \pm 2.4272$ & \multirow{2}{*}{0.001} & $19.2000 \pm 2.8231$ & \multirow{2}{*}{0.001} & $20.1275 \pm 2.7885$ & 0.001 \\
\hline & Left & $20.5850 \pm 2.4887$ & & $18.7000 \pm 2.5203$ & & $19.6425 \pm 2.6735$ & \\
\hline
\end{tabular}


righthanded and lefthanded subjects and measurements of the left auricles of righthanded and lefthanded subjects were not significantly different.

The measurements of the both auricles of righthanded subjects and the measurements of both auricles of the lefthanded subjects were compared in Table IV. Both auricles of the righthanded subjects were statistically significantly different except EL; the values of AL and TIN were higher at the left side and all other measurements had higher values at the right side. All measurements of right and left auricles of lefthanded subjects were statistically significantly different except AW and EL; AL and TIN had higher values at the left side but the values of all other measurements were higher at the right side.

Table III. Comparison of right auricles of the righthanded and lefthanded subjects and left auricles of the righthanded and lefthanded subjects.

\begin{tabular}{|c|c|c|c|c|c|}
\hline \multirow{2}{*}{ Measurement } & \multirow{2}{*}{$\begin{array}{c}\text { Handedness of } \\
\text { the subject }\end{array}$} & \multicolumn{2}{|c|}{ Right auricle } & \multicolumn{2}{|c|}{ Left auricle } \\
\hline & & $\operatorname{Mean} \pm S D$ & $\mathbf{P} *$ & $\operatorname{Mean} \pm \mathbf{S D}$ & $\mathbf{P *}$ \\
\hline \multirow{2}{*}{$\mathbf{A L}$} & Right-handed & $62.3579 \pm 3.9946$ & \multirow{2}{*}{0.645} & $63.3689 \pm 3.9639$ & \multirow{2}{*}{0.264} \\
\hline & Left-handed & $62.4400 \pm 2.9451$ & & $63.9200 \pm 2.8856$ & \\
\hline \multirow{2}{*}{ TIN } & Right-handed & $45.4399 \pm 3.1117$ & \multirow{2}{*}{0.864} & $45.7295 \pm 3.1047$ & \multirow{2}{*}{0.143} \\
\hline & Left-handed & $45.4400 \pm 2.8296$ & & $46.4800 \pm 2.6476$ & \\
\hline \multirow{2}{*}{$\mathbf{A W}$} & Right-handed & $34.1639 \pm 3.2028$ & \multirow{2}{*}{0.698} & $33.1311 \pm 3.2970$ & \multirow{2}{*}{0.908} \\
\hline & Left-handed & $33.7600 \pm 3.4312$ & & $33.2400 \pm 2.7580$ & \\
\hline \multirow{2}{*}{ TH } & Right-handed & $26.4044 \pm 2.7885$ & \multirow{2}{*}{0.275} & $24.9454 \pm 3.0570$ & \multirow{2}{*}{0.204} \\
\hline & Left-handed & $25.7200 \pm 3.1559$ & & $24.1600 \pm 2.4947$ & \\
\hline \multirow{2}{*}{ TAH } & Right-handed & $20.8661 \pm 2.9860$ & \multirow{2}{*}{0.291} & $19.2377 \pm 3.3672$ & \multirow{2}{*}{0.171} \\
\hline & Left-handed & $20.3200 \pm 3.4244$ & & $18.2800 \pm 2.8065$ & \\
\hline \multirow{2}{*}{$\mathbf{E W}$} & Right-handed & $18.9891 \pm 3.4562$ & \multirow{2}{*}{0.764} & $17.2213 \pm 3.2245$ & \multirow{2}{*}{0.810} \\
\hline & Left-handed & $19.3600 \pm 3.3402$ & & $17.6000 \pm 2.6615$ & \\
\hline \multirow{2}{*}{$\mathbf{E L}$} & Right-handed & $17.8934 \pm 2.1215$ & \multirow{2}{*}{0.789} & $17.8470 \pm 2.1603$ & \multirow{2}{*}{0.999} \\
\hline & Left-handed & $17.6000 \pm 2.3629$ & & $17.8000 \pm 2.1602$ & \\
\hline \multirow{2}{*}{$\mathbf{A P}$} & Right-handed & $20.1366 \pm 2.7683$ & \multirow{2}{*}{0.524} & $19.6885 \pm 2.6713$ & \multirow{2}{*}{0.190} \\
\hline & Left-handed & $19.6400 \pm 3.1209$ & & $18.8400 \pm 2.7791$ & \\
\hline
\end{tabular}

Table IV. Comparison of both auricles in the righthanded subjects and both auricles in the lefthanded subjects.

\begin{tabular}{|c|c|c|c|c|c|}
\hline \multirow{2}{*}{ Measurement } & \multirow{2}{*}{$\begin{array}{l}\text { Side of the } \\
\text { auricle }\end{array}$} & \multicolumn{2}{|c|}{ Right-handed subjects } & \multicolumn{2}{|c|}{ Left-handed subjects } \\
\hline & & $\operatorname{Mean} \pm$ SD & $\mathbf{P *}$ & Mean \pm SD & $\mathbf{P *}$ \\
\hline $\mathbf{A L}$ & $\begin{array}{l}\text { Right } \\
\text { Left }\end{array}$ & $\begin{array}{l}62.3579 \pm 3.9946 \\
63.3689 \pm 3.9639\end{array}$ & 0.001 & $\begin{array}{l}62.4400 \pm 2.9451 \\
63.9200 \pm 2.8856\end{array}$ & 0.001 \\
\hline TIN & $\begin{array}{l}\text { Right } \\
\text { Left }\end{array}$ & $\begin{array}{l}45.4399 \pm 3.1117 \\
45.7295 \pm 3.1047\end{array}$ & 0.011 & $\begin{array}{l}45.4400 \pm 2.8296 \\
46.4800 \pm 2.6476\end{array}$ & 0.013 \\
\hline $\mathbf{A W}$ & $\begin{array}{l}\text { Right } \\
\text { Left }\end{array}$ & $\begin{array}{l}34.1639 \pm 3.2028 \\
33.1311 \pm 3.2970\end{array}$ & 0.001 & $\begin{array}{l}33.7600 \pm 3.4312 \\
33.2400 \pm 2.7580\end{array}$ & 0.321 \\
\hline TH & $\begin{array}{l}\text { Right } \\
\text { Left }\end{array}$ & $\begin{array}{l}26.4044 \pm 2.7885 \\
24.9454 \pm 3.0570\end{array}$ & 0.001 & $\begin{array}{l}25.7200 \pm 3.1559 \\
24.1600 \pm 2.4947\end{array}$ & 0.003 \\
\hline TAH & $\begin{array}{l}\text { Right } \\
\text { Left }\end{array}$ & $\begin{array}{l}20.8661 \pm 2.9860 \\
19.2377 \pm 3.3672\end{array}$ & 0.001 & $\begin{array}{l}20.3200 \pm 3.4244 \\
18.2800 \pm 2.8065\end{array}$ & 0.001 \\
\hline $\mathbf{E W}$ & $\begin{array}{l}\text { Right } \\
\text { Left }\end{array}$ & $\begin{array}{l}18.9891 \pm 3.4562 \\
17.2213 \pm 3.2245\end{array}$ & 0.001 & $\begin{array}{l}19.3600 \pm 3.3402 \\
17.6000 \pm 2.6615\end{array}$ & 0.009 \\
\hline $\mathbf{E L}$ & $\begin{array}{l}\text { Right } \\
\text { Left }\end{array}$ & $\begin{array}{l}17.8934 \pm 2.1215 \\
17.8470 \pm 2.1603\end{array}$ & 0.551 & $\begin{array}{l}17.6000 \pm 2.3629 \\
17.8000 \pm 2.1602\end{array}$ & 0.446 \\
\hline $\mathbf{A P}$ & $\begin{array}{l}\text { Right } \\
\text { Left }\end{array}$ & $\begin{array}{l}20.1366 \pm 2.7683 \\
19.6885 \pm 2.6713\end{array}$ & 0.001 & $\begin{array}{l}19.6400 \pm 3.1209 \\
18.8400 \pm 2.7791\end{array}$ & 0.018 \\
\hline
\end{tabular}




\section{DISCUSSION}

Six surface measurements of right auricle in both sexes were performed in a previous study and males had always higher values than females in the 18 year age group although not all of the differences were statistically significant (Kalcioglu et al.). The lengths and the widths of auricle and earlobe had always higher values in males than females on both sides in Turkish primary school students (Barut \& Aktunc). The auricle and earlobe lengths and widths, distances from the tragus to helix and antihelix had higher values in males but auricle projection (AP) was larger in females on both sides in an 18 to 25 years old young Turkish group (Bozkir et al.).

Width and length of the left auricle were measured on a North American Caucasian population and stated that males had higher values than females in 18 year age group (Farkas $e t a l$.). The lengths of both auricles were always larger in males than females of corresponding age in a study from Italy (Ferrario et al., 1999). In an Israeli population, earlobe length was found larger in males than females for both ears and the differences were statistically significant (Azaria et al., 2003). The average values of auricle length, earlobe length and width of right and left auricles were determined in a Rhode Island population and reported as auricle measurements. Auricle and earlobe length were larger in males and earlobe width was larger in females (Brucker at al.). The average values of auricle length and width, and earlobe length of right and left auricles in Caucasian subjects from Netherlands were larger in males than females (Meijerman et al.).

In the present study all measurements of auricle were larger in males for both ears and the differences were statistically significant except earlobe width (EW). The presence of larger auricles in males might be explained with the larger body sizes of males.

Auricle width (AW) was larger at the left side in Turkish primary school students (Barut \& Aktunc). Most of the measurements of auricle were higher on the right side in another study from Turkey (Bozkır et al.).

Auricle length was larger at the left side and auricle width was larger at the right side in both sexes in a study from Italy (Ferrario et al., 1999). In a study on Israeli population earlobe length was larger at the right side in both sexes (Azaria et al.). Auricle length and width had significantly higher values at the right side in an Indian male population. Earlobe length was larger at the right side and earlobe width was larger at the left side but differences were not statistically significant in that population (Purkait \& Singh). In another study on an Indian male population, the length and width of the earlobe were larger on the left side in 21-40 years age group (Sharma et al., 2007). Auricle length was larger at the left side in a Taiwanese population (Liu, 2008).

In the present study, all measurements except AL and TIN were higher on the right side in both sexes. All of the differences were statistically significant except EL in males and TIN and EL in females. It might be an implication for the presence of less asymmetry of auricles in females but it is required to be confirmed with further studies.

Differences between right and left halves of face, especially in paired structures, are well known in human beings (Ferrario et al., 1995). All studies mentioned above were indicating the presence of asymmetry in auricle morphology but the dominant side was not consistent in different studies.

It was proposed that most of the righthanded people had bigger right ears while lefthanded people had bigger left ears in a Korean population (Jung \& Jung). Such a straightforward relation between auricle morphometry and handedness could not be determined in the present study and we do not know of another similar report. Measurements of neither right auricles nor left auricles of righthanders and lefthanders were significantly different in the present study. All measurements of right and lefth auricles of righthanded subjects were statistically significantly different except EL as in the total population. AL and TIN had larger values at the left side and the other measurements were larger at the right side. Lefthanded subjects presented same asymmetries of measurements but in addition to EL, measurements of AW were not significantly different at left and right. It might be said that the auricles of lefthanded subjects were less asymmetric but it is required to be confirmed with further studies as the role of the sex in auricle asymmetry.

It is known that most of the people in human populations are righthanded (Lazenby, 2002). Righthandedness was observed in $91.5 \%$ of subjects in both sexes (183 males and 183 females) in the present study. 13 $(6.5 \%)$ of the males and $12(6.0 \%)$ of the females were lefthanded. Ambidexterity was observed in $4(2.0 \%)$ males and in $5(2.5 \%)$ females. If the dimensions of the auricle would be directly related to handedness, consistent dominance of one side had to be observed in all studies but results of the previous studies are not in line with this idea. 
Some degree of asymmetry of auricles is present in most of the normal human beings and acceptable. Surgeon can sacrifice some degree of symmetry even reverse the asymmetry during the plastic surgeries of the external ear for the requirements of the operation as a chance. Because of the asymmetry of the auricles, devices and appliances prepared for the external ear of a person may be necessary in different sizes. Therefore, it may be useful preparing the parts applied to the auricle as changeable products. Earprints of the right and left auricles in different sizes from the crime scenes does not exclude that they may belong to the same offender.

\section{ACKNOWLEDGEMENTS}

We are grateful to Prof. Gonul Dinc Horasan from the department of Biostatistics and Medical Informatics and Assoc. Prof. Beyhan Cengiz Ozyurt from the department of Public Health for their help in statistical analysis.

TATLISUMAK, E.; YAVUZ, M. S.; KUTLU, N.; ASIRDIZER, M.; YOLERI, L. \& ASLAN, A. Asimetría, lateralidad y morfometría de la oreja. Int. J. Morphol., 33(4):1542-1548, 2015.

RESUMEN: El objetivo de este estudio fue determinar diversas mediciones morfométricas de la oreja, para investigar la asimetría y su relación con el uso de las manos en ambos sexos. Se realizaron mediciones morfométricas de los pabellones auriculares y las manos de 400 estudiantes universitarios (200 hombres y 299 mujeres). Todas las medidas de las orejas fueron mayores en los hombres y todas las diferencias, excepto las correspondientes al ancho del lóbulo auricular, fueron estadísticamente significativas. Todas las mediciones de los pabellones auriculares izquierdos y derechos presentaron diferencias estadísticamente significativas en ambos sexos, excepto en el caso de la longitud del lóbulo auricular en los hombres, y la distancia desde el punto más alto de la oreja a la parte inferior de la incisura intertrágica en el lóbulo auricular de las mujeres. La longitud de la oreja y la distancia desde el punto más alto de la misma a la parte inferior de la escotadura intertrágica tenían valores más altos en el lado izquierdo y todas las demás mediciones fueron más elevadas en el lado derecho. No hubo diferencia significativa entre las mediciones de las orejas correspondientes a los sujetos diestros y zurdos. Todas las mediciones fueron superiores en el lado derecho, excepto la longitud del pabellón auricular y la distancia desde el punto más alto de la oreja a la parte inferior de la incisura intertrágica en sujetos diestros y sujetos zurdos, y todas las diferencias, excepto la longitud del lóbulo auricular, fueron significativamente diferentes en los sujetos diestros como en la población total, pero en sujetos zurdos la diferencia de la anchura de la oreja no fue significativa. Se encontró una aparente asimetría en las orejas derecha e izquierda de los sujetos del presente estudio que debe tenerse en consideración en las cirugías plásticas del oído externo, para el diseño de los dispositivos de audición y para su aplicación en estudios forenses de las huellas de la oreja.

PALABRAS CLAVE: Asimetría; Lateralidad; Oreja, Morfometría; Lateralización; Antropometría.

\section{REFERENCES}

Asirdizer, M.; Tatlisumak, E.; Ozyurt, B. \& Yavuz, M.S. Determination of the usability limits of auricle morphology for identification. J. Forensic Med., 26(2):104-14, 2012.

Azaria, R.; Adler, N.; Silfen, R.; Regev, D. \& Hauben, D. J. Morphometry of the adult human earlobe: a study of 547 subjects and clinical application. Plast. Reconstr. Surg., 111(7):2398-402, 2003.

Barut, C. \& Aktunc, E. Anthropometric measurements of the external ear in a group of Turkish primary school students. Aesthetic Plast. Surg., 30(2):255-9, 2006.

Bozkir, M. G.; Karakas, P.; Yavuz, M. \& Dere, F. Morphometry of the external ear in our adult population. Aesthetic Plast. Surg., 30(1):81-5, 2006.

Brucker, M. J.; Patel, J.; Sullivan, P. K. A morphometric study of the external ear: age- and sex-related differences. Plast. Reconstr. Surg., 112(2):647-52, 2003.

Farkas, L. G.; Posnick, J. C. \& Hreczko, T. M. Anthropometric growth study of the ear. Cleft Palate Craniofac. J., 29(4):3249, 1992.

Feenstra, L. \& van der Lugt, C. Ear witness. J. Laryngol. Otol., 114(7):497-500, 2000.

Ferrario, V. F.; Sforza, C.; Miani, A. Jr. \& Serrao, G. A threedimensional evaluation of human facial asymmetry. J. Anat., 186(Pt. 1):103-10, 1995.

Ferrario, V. F.; Sforza, C.; Ciusa, V.; Serrao, G. \& Tartaglia, G. M. Morphometry of the normal human ear: a cross-sectional study from adolescence to mid-adulthood. J. Craniofac. Genet. Dev. Biol., 19(4):226-33, 1999.

Jung, H. S. \& Jung, H. S. Surveying the dimensions and characteristics of Korean ears for the ergonomic design of ear-related products. Int. J. Ind. Ergon., 31(6):361$73,2003$. 
TATLISUMAK, E.; YAVUZ, M. S.; KUTLU, N.; ASIRDIZER, M.; YOLERI, L. \& ASLAN, A. Asymmetry, handedness and auricle morphometry. Int. J. Morphol., 33(4):1542-1548, 2015.

Kalcioglu, M. T.; Miman, M. C.; Toplu, Y.; Yakinci, C. \& Ozturan, O. Anthropometric growth study of normal human auricle. Int. J. Pediatr. Otorhinolaryngol., 67(11):1169-77, 2003.

Lazenby, R. Skeletal biology, functional asymmetry and the origins of "Handedness". J. Theor. Biol., 218(1):129-38, 2002.

Liu, B. S. Incorporating anthropometry into design of ear-related products. Appl. Ergon., 39(1):115-21, 2008.

Meijerman, L.; van der Lugt, C. \& Maat, G. J. Cross-sectional anthropometric study of the external ear. J. Forensic Sci., 52(2):286-93, 2007

Oldfield, R. C. The assessment and analysis of handedness: the Edinburgh inventory. Neuropsychologia, 9(1):97-113, 1971.

Purkait, R. \& Singh, P. Anthropometry of the normal human auricle: a study of adult Indian men. Aesthetic Plast. Surg., 31(4):3729, 2007.

Sharma, A.; Sidhu, N. K.; Sharma, M. K.; Kapoor, K. \& Singh, B. Morphometric study of ear lobule in northwest Indian male subjects. Anat. Sci. Int., 82(2):98-104, 2007.

van der Lugt, C.; Nagelkerke, N. J. \& Maat, G. J. Study of the relationship between a person's stature and the height of an ear imprint from the floor. Med. Sci. Law, 45(2):135-41, 2005.
Correspondence to:

Ertugrul Tatlisumak, M.D., Assoc. Prof.

Department of Anatomy

Medical Faculty of Celal Bayar University

45030, Manisa

TURKEY

Telephone: +90-236 2331920 \# 410

Fax: $+90-2362331466$

Email: ertugrul40@yahoo.com

Received: 09-05-2014

Accepted: 07-07-2014 